\title{
BIOPESTISIDA DARI EKSTRAK DAUN PANGI (Pangium sp.) TERHADAP SERANGGA Plutella xylostella DI SULAWESI UTARA
}

\author{
BIOPESTICIDE OF PANGI LEAF EXTRACT (Pangium sp.) AGAINST Plutella xylostella \\ INSECTS IN NORTH SULAWESI
}

\author{
Christina L. Salaki1), Evie Paendong'2) dan Jantje Pelealu1) \\ 1) Fakultas Pertanian Unsrat Manado \\ 2) Fakultas MIPA, Universitas Negeri Gorontalo
}

\begin{abstract}
Searching the plants in which can produce biopesticides, such as antifeedant to control the insect pests, it attracted the attention of worldwide researches. It is due to in the crop protection, the compounds of antifeedant do not kill, repel or entrap insects, but just inhibit the insect's appetite, so that the food crops or the commodity can be protected. Plutella xylostella $(\mathrm{L})$ is the insect pests which is cosmopolitantly distributed in. Its attacks could damage vegetables resulting in loss of quantitative and qualitative. To overcome these problems, need to develop a means of pest control, which are effective but environmental friendly. North Sulawesi has a lot of plants, which is potentially developed as a source of botanical insecticides. Pangi Plant (Pangium sp.) is a plant species which potentially developed and effective against several types of insect pests, but testing by using crude extract can give varies results depending on the type of extract used, the test insects and environment factors. The purpose of this study was to determine the potential of leaf extracts pangi (Pangium sp.) as antifeedant against Plutella xylostella. The method used is the method of Qin et al. (2004). To determine the class of active compounds to extract the thick antifeedant have done by taking each extract to make a concentrations of $1 \%(\mathrm{w} / \mathrm{v}), 5 \%(\mathrm{w} / \mathrm{v})$, and $10 \%(\mathrm{w} / \mathrm{v})$. Data were analyzed by Analysis of Variance (One-way ANOVA). The results showed that, the leaf extract of condensed pangi were able to inhibit the feeding activity of the larvae of $P$. xylostella.
\end{abstract}

Keywords : biopesticide, Pangium sp., Plutella xylostella

\section{ABSTRAK}

Penelusuran tumbuh-tumbuhan yang dapat menghasilkan biopestisida, seperti anti makan (antifeedant) untuk mengendalikan hama serangga, sangat menarik perhatian para peneliti di seluruh dunia. Hal ini disebabkan karena dalam perlindungan tanaman, senyawa anti makan tidak membunuh, mengusir atau menjerat serangga hama, tetapi hanya menghambat selera makan dari serangga tersebut, sehingga tanaman pangan atau komoditi dapat terlindungi. Plutella xylostella (L) merupakan serangga hama yang penyebarannya bersifat kosmopolitan. Serangan ini dapat merusak tanaman sayuran mengakibatkan kehilangan hasil secara kuantitatif maupun kualitatif. Untuk mengatasi permasalahan tersebut, perlu dikembangkan sarana pengendalian hama yang efektif tetapi ramah lingkungan. Sulawesi Utara memiliki banyak tumbuhan yang berpotensi untuk dikembangkan sebagai sumber insektisida botani. Tanaman pangi (Pangium sp.) adalah jenis tumbuhan yang berpotensi untuk dikembangkan dan efektif terhadap beberapa jenis serangga hama, namun pengujian dengan menggunakan ekstrak kasar dapat memberikan hasil yang beragam tergantung dari jenis ekstrak yang digunakan, faktor serangga uji dan lingkungan. Tujuan penelitian ini adalah untuk mengetahui potensi ekstrak daun pangi (Pangium sp.) sebagai anti makan terhadap $P$. xylostella. Metode yang digunakan adalah metode Qin et al. (2004). Untuk mengetahui golongan senyawa aktif anti makan terhadap ekstrak kental dilakukan dengan mengambil masing-masing ekstrak untuk dibuat konsentrasi $1 \%(\mathrm{~b} / \mathrm{v})$, $5 \%(\mathrm{~b} / \mathrm{v})$, dan $10 \%(\mathrm{~b} / \mathrm{v})$. Data dianalisa dengan analisis varians (One-way Anova). Hasil penelitian menunjukkan bahwa Ekstrak kental daun pangi mampu menghambat aktivitas makan dari larva $P$. xylostella.

Kata Kunci : biopestisida, Pangium sp., Plutella xylostella 


\section{PENDAHULUAN}

Penelusuran tumbuh-tumbuhan yang dapat menghasilkan biopestisida, seperti anti makan (antifeedant) untuk mengendalikan hama serangga, sangat menarik perhatian para peneliti di seluruh dunia. Hal ini disebabkan karena dalam perlindungan tanaman, senyawa anti makan tidak membunuh, mengusir atau menjerat serangga hama, tetapi hanya menghambat selera makan dari serangga tersebut, sehingga tanaman pangan atau tanaman komoditi dapat terlindungi. Selain itu, senyawa anti makan sangat spesifik terhadap serangga sasaran, karena tidak mengganggu serangga lain sehingga tidak berpengaruh terhadap kelangsungan hidup organisme lainnya. Senyawa anti makan adalah suatu zat yang jika diujikan terhadap serangga akan menghentikan nafsu makan secara sementara atau permanen (Leatemia dan Murray, 2004; Ling dkk., 2008).

Beberapa senyawa anti makan yang telah berhasil diisolasi dari tumbuhan, diantaranya adalah senyawa isopimpinolin, bergapten, santotoksin, dan japonin dari daun Orixa japonica yang aktif anti makan terhadap Spodoptera littura F (Yajima dkk., 1977). Kubo dkk. (1980) berhasil mengisolasi plumbagin, suatu senyawa naftokuinon dari Plumbago capenensis yang berpotensi sebagai anti makan terhadap ulat tentara (Army worm) dari Afrika. Selain itu lima senyawa turunan kromen yang secara struktur berkaitan dengan benzopuran telah berhasil diisolasi dari salah satu species tumbuhan pada famili Astaceae, yang mana senyawa ini bersifat racun kontak dan antimakan terhadap Spodoptera littoralis (Srivastava dan Proksch, 1990).

Ide pemanfaatan senyawa-senyawa kimia dari tumbuhan yang dapat menghambat aktivitas makan serangga sebagai agen pengendali serangga hama telah menarik banyak perhatian para peneliti. Pengendalian serangga hama menggunakan senyawa-senyawa yang bersifat menghambat aktivitas makan memberikan beberapa kelebihan seperti tidak menimbulkan resistensi, selektivitas yang tinggi, mudah terdegradasi, dan relatif tidak beracun terhadap manusia. Senyawa kimia yang berasal dari tumbuhan dan mempunyai kelebihan seperti yang disebutkan di atas dapat digunakan sebagai penghambatan makan insektisida.

Secara umum, hama tanaman tidak dapat dihilangkan secara total, tetapi perlu dilakukan upaya-upaya untuk menurunkan populasi hama perlu dilakukan. Aplikasi senyawa-senyawa yang dapat bersifat sebagai penghambat aktivitas makan serangga mungkin dapat memberikan kontribusi dalam kegiatan pengendalian serangga hama. Penggunaan secara praktis senyawa-senyawa penghambat aktivitas makan serangga dapat dilakukan pada beberapa tahap dalam budidaya tanaman seperti pembibitan, pertumbuhan, dan prapanen.

Salah satu kendala utama dalam sistem produksi di Indonesia adalah adanya serangan hama dan penyakit pada tanaman sayuran. Plutella xylostella (L) merupakan serangga hama yang penyebarannya bersifat kosmopolitan (Qin et al., 2004; Rismansyah, 2008; Suharto, 2004). Serangga ini sering digunakan sebagai bioindikator karena larva ini sangat agresif dan rakus memakan daun tumbuhan uji di samping murah dan mudah didapatkan. Serangan serangga ini dapat merusak tanaman sayuran mengakibatkan kehilangan hasil secara kuantitatif maupun kualitatif. Di Indonesia, strategi pengendalian yang sangat umum dilakukan untuk menekan populasi serangga tersebut adalah dengan aplikasi insektisida sintetik.

Akan tetapi penggunaan insektisida tersebut sering meninggalkan residu yang berbahaya terhadap lingkungan dan kesehatan manusia (Untung, 2006). Di samping harga insektisida sintetik yang mahal, dampak dari adanya residu insektida sintetik dalam bidang ekonomi adalah ekspor oleh banyak Negara tujuan ekspor atas produk-produk sayuran yang mengandung residu fungisida dan pestisida lain. Kekhawatiran akan dampak negatif dari penggunaan insektisida sintetik tersebut menimbulkan kebutuhan akan adanya alternatif baru yang dapat dipakai untuk mengendalikan populasi hama dan serangga vektor sampai pada tingkat yang tidak merugikan secara ekonomi.

Untuk mengatasi permasalahan tersebut, perlu dikembangkan sarana pengendalian hama 
yang efektif tetapi ramah lingkungan. Salah satu sarana pengendalian yang memiliki peluang baik untuk dikembangkan dalam menunjang penerapan PHT adalah pemanfaatan bahan insektisida yang berasal dari tumbuhan karena relatif aman terhadap musuh alami, memiliki tingkat persistensi yang singkat sehingga tidak dikuatirkan meninggalkan residu, tidak mencemari lingkungan, dan dapat bekerja secara kompatibel dengan pengendalian hayati (Sembel, 2010).

Sulawesi Utara memiliki banyak tumbuhan yang berpotensi untuk dikembangkan sebagai sumber insektisida botani. Tanaman pangi (Pangium sp.) adalah jenis tumbuhan yang berpotensi untuk dikembangkan dan efektif terhadap beberapa jenis serangga hama, namun pengujian dengan menggunakan ekstrak kasar dapat memberikan hasil yang beragam tergantung dari jenis ekstrak yang digunakan, faktor serangga uji dan lingkungan. Walaupun demikian menurut Kardinan (2000), sediaan insektisida botani yang efektif di suatu tempat belum tentu efektif di tempat lain. Salah satu penyebabnya adalah jumlah kandungan bahan aktif yang dimiliki oleh spesies tumbuhan yang sama seringkali berbeda tergantung dari keadaan geografi daerah asal tumbuhan tersebut, sehingga dosis atau konsentrasi yang digunakannya juga akan berbeda.

Penelitian ini bertujuan untuk mengetahui pengaruh ekstrak daun pangi (Pangium Sp.) terhadap perkembangan hama $P$. xylostella dan mengetahui daya bunuh ekstrak daun pangi (Pangium Sp.) terhadap perkembangan hama $P$. xylostella. Hasil penelitian diharapkan dapat memberikan informasi tentang senyawa anti makan yang terdapat pada daun pangi yang nantinya dapat dimanfaatkan sebagai pestisida alami untuk mengendalikan hama kubis $P$. xylostella.

\section{METODE PENELITIAN}

Penelitian ini dilakukan di Laboratorium Entomologi Fakultas Pertanian Universitas Sam Ratulangi Manado, mencakup ekstraksi senyawa daun pangi dan uji anti makan senyawa tersebut. Lamanya kegiatan penelitian adalah 6 bulan yakni dari bulan Juni sampai bulan November 2012.

\section{Ekstraksi Senyawa Aktif Anti makan}

Masing-masing serbuk daun pangi sebanyak $5500 \mathrm{~g}$ dimaserasi dengan $15 \mathrm{~L}$ metanol dan n-heksana sampai semua komponen terekstraksi. Ekstrak metanol dan n-heksana yang diperoleh, disaring kemudian diuapkan dengan menggunakan penguap putar vakum sampai diperoleh ekstrak kental metanol dan n-heksana. Ekstrak kental metanol dilarutkan kembali dengan metanol kemudian dipartisi dengan $n$-heksana $12 \mathrm{X}$ $20 \mathrm{~mL}$ sehingga diperoleh ekstrak $n$-heksana dan ekstrak metanol. Ekstrak n-heksana dan ekstrak metanol diuapkan hingga diperoleh ekstrak kental n-heksana dan ekstrak kental metanol. Kedua ekstrak kemudian diuji anti makan. Ekstrak kental dengan aktivitas antimakan terbesar dilanjutkan pada proses pemisahan dan pemurnian.

\section{Uji Hayati Anti makan}

Uji hayati anti makan dilakukan sesuai metode Qin $d k k$., 2004. Untuk mengetahui golongan senyawa aktif anti makan terhadap ekstrak kental dilakukan dengan mengambil masing-masing ekstrak untuk dibuat konsentrasi $1 \%(b / v), 5 \%(b / v)$, dan 10\% (b/v). Larutan uji ini dioleskan merata pada bagian belakang dari media uji (daun kubis) dengan menggunakan kuas pada paruh kiri sedangkan pelarut pada paruh kanan sebagai kontrol, lalu dikeringkan. Pelarut yang digunakan untuk kontrol sesuai dengan pelarut dari ekstrak kentalnya. Daun media uji dimasukkan ke dalam cawan petri yang sudah diberi lapisan kain kasa atau kapas basah untuk kelembaban. Daun ditutup dengan petri yang lebih kecil yang diberi lubang ditengahnya dengan diameter $3,5 \mathrm{~cm}$. Di atas penutup daun diletakkan 5 ekor larva $P$. xylostella yang telah dipuasakan selama empat jam, kemudian diinkubasi pada suhu kamar selama 24 jam, Setelah 24 jam daun media uji diambil dan dilakukan perhitungan luas daun yang dikomsumsi hewan uji. Uji aktivitas anti makan terhadap fraksi hasil kolom kromatografi maupun isolat dilakukan dengan cara yang sama.

Cara menghitung luas daun adalah dengan membuat lingkaran plastik transparan berdiameter $3,5 \mathrm{~cm}$ dan membaginya menjadi 32 sektor. Pembagian lingkaran menjadi 32 sektor seperti ditunjukkan pada Gambar 1. 


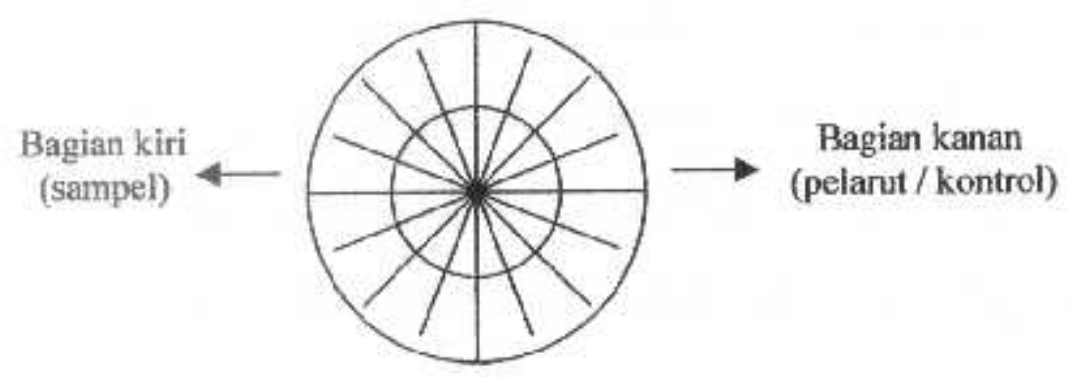

Gambar 1. Cara Menghitung Luas Area Aktif Hambatan Makan Ekstrak Daun Pangi (Pangium sp) Terhadap Larva P. xylostella.

(Figure 1. Calculate the Area of Active Constraints Eating Area Pangi Leaf Extract (Pangium sp) Against Larvae of P. xylostella)

Perhitungan aktivitas anti makan menggunakan rumus sebagai berikut :

Luas sektor yang dikonsumsi (bagian kanan - bagian kiri)

Luas sektor yang dikonsumsi (bagian kanan + bagian kiri) $x 100 \%$

Analisis Data

Penentuan Sumber Data

Populasi

Populasi target dari penelitian ini adalah serangga $P$. xylostella yang ditemukan di perkebunan hortikultura, sedangkan populasi terjangkau adalah serangga P. xylostella yang dibiakkan dan dipuasakan khusus untuk penelitian ini.

\section{Kriteria Inklusi dan Eksklusi}

Sampel penelitian adalah larva $P$. xylostella dengan kriteria inklusi berberat badan 5 $g$ dan berumur 7-12 hari yaitu pada instar 3 dan 4 . Kriteria eksklusi adalah serangga $P$. xylostella dengan kondisi umur kurang dari 7 hari atau pada kondisi instar 1 dan 2.

\section{Besar Sampel}

Sampel diambil secara acak sistematik dan diambil jumlah lot terkecil yaitu masing-masing 2 ekor larva. Untuk mendapatkan data yang valid dilakukan pengulangan yang dihitung berdasarkan rumus Federer (1963) dalam Rochiman (1989), sebagai berikut:

Dimana;

$$
(t-1)(n-1) \geq 15
$$

$\mathrm{t}=$ banyaknya perlakuan

$\mathrm{n}=$ banyaknya ulangan
Dalam penelitian ini $t=5$, sehingga (5-1) $(\mathrm{n}-1) \geq 15$ dan didapatkan $\mathrm{n}=5$. Larva $P$. xylostella sebanyak 25 ekor ditempatkan pada 25 kandang yang sudah diberi label perlakuan dan diambil secara acak, sehingga setiap kandang terdiri dari 5 ekor larva yang diberi makanan sesuai dengan pelaksanaan penelitian (Tabel 1).

\section{Variabel Penelitian}

\section{Klasifikasi Variabel}

Variabel dalam penelitian ini diklasifikasikan menjadi: variabel bebas: konsentrasi ekstrak metanol dan heksan daun pangi, variabel tergantung: penghambatan makan larva $P$. xylostella, variabel kontrol: umur, berat badan $P$. xylostella, waktu penelitian, dan alat ukur.

\section{HASIL DAN PEMBAHASAN}

Hasil pengujian ekstrak kental 5500 gram daun pangi (Pangium sp.) terhadap hama Plutella xylostella dapat dilihat pada Gambar 2. Setiap konsentrasi diujikan pada 30 larva P. xylostella yang diambil dari lapang dan dipuasakan selama 4 jam. 
Tabel 1. Pemberian Perlakuan Ekstrak Daun Pangi Masing-masing untuk P. xylostella

(Table 1. The Provision Pangi Leaf Extract Treatment Respectively for P. xylostella)

\begin{tabular}{cccccc}
\hline Perlakuan & I & II & III & IV & V \\
\hline P0 & 5 ekor & 5 ekor & 5 ekor & 5 ekor & 5 ekor \\
P1 & 5 ekor & 5 ekor & 5 ekor & 5 ekor & 5 ekor \\
P2 & 5 ekor & 5 ekor & 5 ekor & 5 ekor & 5 ekor \\
P3 & 5 ekor & 5 ekor & 5 ekor & 5 ekor & 5 ekor \\
P4 & 5 ekor & 5 ekor & 5 ekor & 5 ekor & 5 ekor \\
\hline
\end{tabular}

Keterangan : Perlakuan P0 (sebagai kontrol) dilakukan 5 kali pengulangan, $\mathrm{P} 1=10 \mathrm{mg} / \mathrm{g} \mathrm{BB}, \mathrm{P} 2=15 \mathrm{mg} / \mathrm{g}$ $\mathrm{BB}, \mathrm{P} 3=20 \mathrm{mg} / \mathrm{g} \mathrm{BB}$, dan $\mathrm{P} 4=20 \mathrm{mg} / \mathrm{g} \mathrm{BB}$.

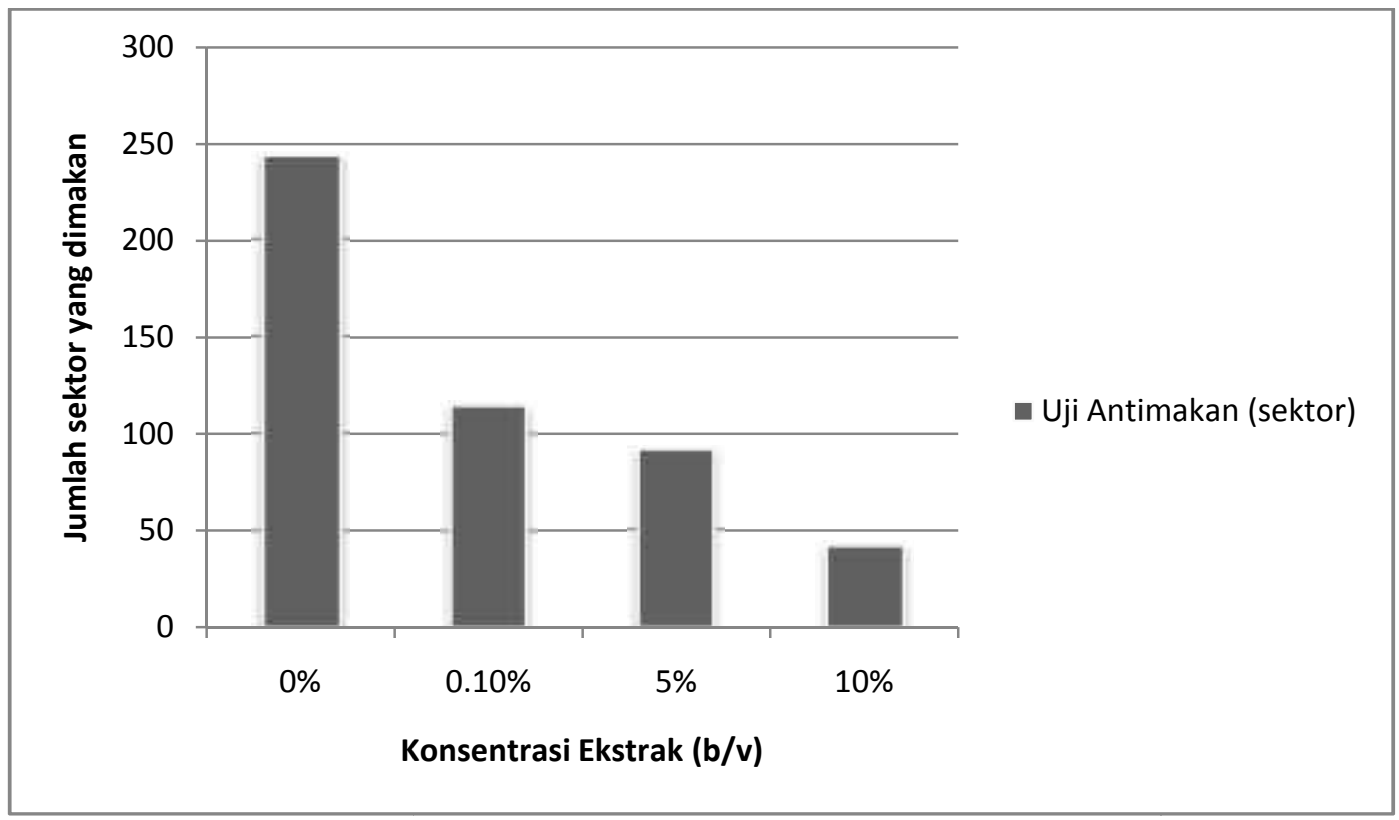

Gambar 2. Kurva Uji Anti makan Ekstrak Daun Pangi Berdasarkan Tingkat Konsentrasi terhadap Larva Plutella xylostella

(Figure 2. Test Curve Anti makan Pangi Leaf Extract Concentration Levels Based on Plutella xylostella larvae)

Pengamatan menunjukkan bahwa pada konsentrasi $0,1 \%(b / v)$, jumlah sektor yang dimakan oleh larva adalah 151 sektor kemudian pada konsentrasi $5 \%(b / v)$, jumlah sektor yang dimakan menurun pada 91 sektor dan konsentrasi $10 \%(\mathrm{~b} / \mathrm{v})$, jumlah sektor yang dimakan menunjukkan penurunan jauh yaitu 42 sektor.

Dari hasil pengamatan juga menunjukkan bahwa penurunan jumlah sektor yang dimakan oleh larva sebanding dengan kenaikan konsentrasi ekstrak yang diujikan. Hal ini menjelaskan bahwa ekstrak daun pangi dapat menjadi antifeedant bagi P. xylostella. Hasil uji penghambatan aktivitas makan disimpulkan bahwa ekstrak heksana pada sampel daun pangi dalam keadaan segar memiliki aktivitas yang tinggi terutama pada konsentrasi
10\% (Ahmad, 1998; Asikin dan Thamrin, 2002; Miles et al., 1985).

Uji statistik menunjukkan bahwa variasi konsentrasi berpengaruh pada terhadap penghambatan aktivitas makan larva $P$. xylostella. Pengaruh konsentrasi $10 \%$ (b/v) berbeda nyata dengan kedua konsentrasi dan kontrol. Sedangkan, konsentrasi $5 \%(\mathrm{~b} / \mathrm{v})$ tidak berbeda nyata dengan konsentrasi $10 \%(\mathrm{~b} / \mathrm{v})$ tetapi berbeda nyata terhadap konsentrasi $1 \%$ dan kontrol.

Gustini et al. (2007) melaporkan bahwa ektrak heksana sampel daun pangi kering memiliki persen penghambatan aktivitas makan dan mortalitas tertinggi pada larva instar III Spodoptera litura, sedangkan yang terendah ditunjukkan oleh ekstrak air sampel daun pangi segar. 
Tanaman pangi sering digunakan sebagai pestisida nabati terlebih khusus untuk daun dan biji dari tanaman tersebut. Selain daun pangi, ekstrak daging biji pangi juga dapat bertindak sebagai pestisida nabati. Asrori (2008) menyatakan bahwa semua taraf konsentrasi ekstrak yang diujikan mampu menghambat pertumbuhan diameter koloni Rhizoctonia sp. secara nyata. Konsentrasi ekstrak daging biji pangi 100\% memberikan tingkat persentase penghambatan sebesar $39.34 \%$.

Ekstrak dari biji pangi dapat digunakan sebagai rodentisida nabati karena pada daging biji tanaman pangi mengandung senyawa sianida yang tinggi. Untuk dapat mematikan tikus dengan berat badan $30 \mathrm{~g}$ dalam waktu kurang dari 5 menit diperlukan pemberian (cekok) sebanyak $0,8 \mathrm{ml}$ larutan biji picung dengan konsentrasi 100\% (b/v, 2.800 ppm sianida) (Yuningsih dan Damayanti, 2008).

Ekstrak biji pangi juga dapat digunakan sebagai moluskisida nabati. Kematian 100\% keong mas (berat badan rata-rata 5-12 g) dengan cara perendaman dalam larutan ekstrak air biji picung yang mengandung 25-50 ppm sianida (Yuningsih dan Kartina, 2007). Senyawa kimia yang bersifat iritasi dan mudah larut dalam air akan mempercepat kematian moluska. Hal ini dapat terjadi karena terjadi adsorpsi (efek iritasi) pada permukaan cangkang moluska dan dengan cepat terjadi reaksi langsung senyawa kimia tersebut dengan bagian dalam tubuhnya. Sementara kedua sifat iritasi dan mudah larut dalam air tersebut merupakan sifat dari kedua senyawa benzaldehida dan sianida (hasil hidrolisis) yang terdapat dalam biji picung, sehingga biji picung cukup efektif sebagai moluskisida dan dapat dijadikan sebagai salah satu upaya pengganti moluskisida sintetik. Diharapkan pula dapat meminimalisasi serangan hama keong mas yang masih banyak ditemukan di daerah pesawahan, yaitu sekitar $80-100 \%$ seluruh provinsi di Indonesia. Sementara di Kalimantan Selatan, para peternak kerbau rawa mengeluh karena mengalami kesulitan dalam memperoleh hijauan yang habis dimakan oleh keong mas (Yuningsih, 2008).

\section{KESIMPULAN DAN SARAN}

\section{Kesimpulan}

Ekstrak kental daun pangi mampu menghambat aktivitas makan dari larva Plutella xylostella. Perlakuan dengan menggunakan konsentrasi $10 \%$ berpengaruh nyata terhadap larva $P$. xylostella dalam penghambatan aktivitas makan. Dari hasil penelitian juga diperoleh kesimpulan bahwa semakin tinggi konsentrasi yang diberikan maka semakin kecil jumlah luas makan (sektor) oleh larva $P$. xylostella.

\section{Saran}

Perlu dilakukan penelitian lebih lanjut mengenai efektifitas ekstrak daun pangi baik segar maupun kering dan menggunakan pelarut yang berbeda.

\section{DAFTAR PUSTAKA}

Ahmad, I. 1998. Dosage Mortality Study with Bacillus thuringiensis and Neem Extract on Diamondback Moth, Plutella xylostella (Lepidoptera: Plutellidae). Journal Perlindungan Tanaman Indonesia. 10 (3):9194.

Asikin, S. dan M. Thamrin. 2002. Bahan Tumbuhan Sebagai Pengendali Hama Ramah Lingkungan. Disampaikan pada Seminar Nasional Lahan Kering Dan Lahan Rawa 18-19 Desember 2002. BPTP Kalimantan Selatan dan Balittra. Banjar Baru.

Asrori, A. 2008. Efektivitas Penghambatan Ekstrak Daging Biji Picung (Pangium edule Reinw.) Terhadap Pertumbuhan Rhizoctonia sp. Secara In Vitro. Skripsi. Institut Pertanian Bogor. http://repository.ipb.ac.id/bitstream/ handle/123456789/11604/E08aas.pdf?seq uence $=2$. Di akses tanggal 4 Desember 2012.

Capinera, J.L. 2000. Plutella xylostella Linn. http://creatures.ifas.ufl.edu/veg/leaf/diamo ndbackpupa.html. Diakses tanggal 26 Nopember 2007. 
Kardinan. 2002. Pestisida Nabati Ramuan dan Aplikasi. Jakarta; Penebar Swadaya.

Kubo, L., M. Tamguchi, A. Chapya, and K. Tsujimoto. 1980, An Insect Antifeedant and Antimicrobial Agent from Plumbago capenensis, Journal of Medicinal Plant Reseach, Suplement, 185-187.

Leatemia, J. A. and B.I. Murray. 2004. Toxicity and antifeedant activity of crude seed extracts of Annona squamosa (Annonaceae) against lepidopteran pests and natural enemies. International Journal of Tropical Insect Science. 24: p.150-158.

Ling, B., Guo-cai, W., Ji, Y., Mao-xin, Z., and Guang-wen, L. 2008. Antifeedant Activity and Active Ingredients Against Plutella xylostella from Momordica charantia Leaves. Agircultural Sciences in China. 7(12): p. 1466-1473.

Miles, D.H., L. H. Barbara, and A. S. Randle. 1985. Insect Antifeedant from the Peruvian Plants Alchornea triplinenvia, Am. Chem. Soc. J. ACS Symposium Series, 470-476.

Qin, W.Q., Z.Q. Peng, and B. Ling. 2004. Oviposition deterring and anti-feeding effect of extracts of 20 tropical plants on diamondback moth (Plutella xylostella). Chinese Journal of Tropical Crops. 1: 4953.

Rismansyah, E.A. 2008. Picung (Pangium edule) Sebagai Pengawet dan Pestisida Alami. Warta penelitian dan pengembangan tanaman industri. 14 (3): hal 7-8.

Sembel. D.T. 2010. Pengantar Pengendalian Hama Serangga Tropis dan Gulma. Andi Offset. Yogyakarta.
Suharto. 2004. Pathogenicity of Beauveria bassiana Isolates on Plutella xylostella. Jurnal Perlindungan Tanaman Indonesia. 10(2):812.

2007. Pengenalan dan Pengendalian Hama Tanaman Pangan. Andi-Yogyakarta

Srivastava, P. R., and P. Proksch. 1990. Toxicity and Feeding Deterrence of Natural Chromene and Bensofuran Derivates to Epilachna Parivestis. Naturwissenchepten. 77: p. 438-439.

Untung, K. 2006. Pengantar Pengelolaan Hama Terpadu. Gadjah Mada University Press. Yogyakarta.

Yajima, T. N., K. Kato, and Munakata. 1977. Isolation of Insect Antifeeding Principles in Orixa japonica Thumb, Agric. Biol Chem, 41, 1263-1268.

Yuningsih. 2008. Kandungan dan Stabilitas Sianida Dalam Tanaman Picung (Pangium edule Reinw.) Serta Pemanfaatannya. Jurnal Balai Besar Penelitian Veteriner. http://balittro.litbang.deptan.go.id/ind/imag es/stories/edsus/vol20n02/4stabilitas.pdf. di akses tanggal 4 Desember 2012.

Yuningsih dan G. Kartina. 2007. Efektivitas Ekstrak Biji Picung (Pangium edule Reinw) Terhadap Mortalitas Keong Mas (Pomacea canaliculata Lamarck). Berita Biologi 8 (4) : 307-310.

Yuningsih dan R. Damayanti. 2008. Studi awal: Efektivitas Ekstrak Biji Picung (Pangium edule Reinw.) terhadap Mencit dan anjing sebagai pengganti Racun Strychnine dalam Upaya Eliminasi Anjing Liar. Buletin Penelitian Tanaman Rempah dan Obat. 19 (1) : 86-94. 
